\title{
Cash holdings and business group membership ${ }^{\text {th }}$
}

\author{
Rosy Locorotondo ${ }^{\mathrm{a}, *}$, Nico Dewaelheyns ${ }^{\mathrm{b}, 1}$, Cynthia Van Hulle ${ }^{\text {c, } 2}$ \\ ${ }^{a}$ Research Foundation Flanders \& Katholieke Universiteit Leuven, Belgium \\ ${ }^{\mathrm{b}}$ Lessius University College E' Katholieke Universiteit Leuven, Belgium \\ ${ }^{\mathrm{c}}$ Katholieke Universiteit Leuven, Belgium
}

\section{A R T I C L E I N F O}

\section{Article history:}

Received 1 February 2012

Received in revised form 1 August 2012

Accepted 23 January 2013

Available online $\mathrm{xxxx}$

\section{Keywords:}

Cash holdings

Internal capital markets

Business groups

Moral hazard

Financial distress

\begin{abstract}
A B S T R A C T
This study examines the cash policies of business group members (i.e., affiliates). Using a panel dataset of private Belgian affiliates and comparable non-affiliated firms, the empirical results show that business group affiliates hold significantly smaller amounts of cash as compared to non-affiliated firms. This finding is consistent with the notion that affiliates can afford to keep lower cash reserves because these firms can access the internal capital market of the group. The analysis also combines affiliate level and group level data to evaluate cash drivers and shows that groups in financial distress reduce cash holdings in affiliates. However, affiliates that are more important for the group's reputation and operations maintain cash levels comparable to affiliates belonging to financially healthy groups.
\end{abstract}

(c) 2013 Elsevier Inc. All rights reserved.

\section{Introduction}

Both U.S. and European firms hold considerable amounts of cash on their balance sheets because of the presence of market imperfections such as information asymmetries, agency problems, transactions costs, and costs of financial distress (e.g., Chen \& Chuang, 2009; Ferreira \& Vilela, 2004; Iskandar-Datta \& Yonghong, 2012).

The cash literature predominantly views the firm as a freestanding company. Yet, in non-Anglo-Saxon countries, many firms have corporate block holders (e.g., La Porta, Lopez de Silanes, Shleifer, \& Vishny, 1999). For example, more than half of the largest European nonfinancial firms have a dominant corporate shareholder (Bureau van Dijk's Amadeus database, version 2009). This type of ownership

\footnotetext{
The authors thank Bert D'Espallier, Hogeschool-Universiteit Brussel, Pedro Juan García-Teruel, Universidad de Murcia, Mónica López-Puertas Lamy, Universitat Autonoma de Barcelona, Jens Martin, Universiteit van Amsterdam, Randy Priem, Katholieke Universiteit Leuven, Frederiek Schoubben, Lessius University College, Sander Van Konnegem, Katholieke Universiteit Leuven, Gunther Wuyts, Katholieke Universiteit Leuven, the participants of the 2010 Corporate Finance Day, the 2011 Campus for Finance Research Conference, the 2011 FMA European conference, the 2011 World Finance Conference, and two anonymous referees for constructive comments. This research was supported by project grants from the Research Foundation Flanders (FWO).

* Corresponding author at: The Research Foundation - Flanders (FWO) \& Katholieke Universiteit Leuven, Faculty of Business and Economics, AFI, Naamsestraat 69, 3000 Leuven, Belgium. Tel.: + 3216326618 .

E-mail address: rosy.locorotondo@econ.kuleuven.be (R. Locorotondo).

${ }^{1}$ Lessius University College, Department of Business Studies, Korte Nieuwstraat 33, 2000 Antwerp, Belgium \& Katholieke Universiteit Leuven, Faculty of Business and Economics, AFI, Naamsestraat 69, 3000 Leuven, Belgium.

${ }^{2}$ Katholieke Universiteit Leuven, Faculty of Business and Economics, AFI, Naamsestraat 69, 3000 Leuven, Belgium.
}

often results in the creation of a business group, where common stable and long-term equity ownership links legally independent firms together under the control of a corporate owner (i.e., the parent firm) that provides managerial coordination and/or administrative and financial control (Yiu, Lu, Bruton, \& Hoskisson, 2007).

Group membership may have a significant impact on firms' cash policies. Business groups establish internal capital markets that lower information asymmetries and alleviate financial constraints (e.g., Schiantarelli \& Sembenelli, 2000). Intra-group guarantees and group reputation can also improve the availability of external financing (Chang \& Hong, 2000). By contrast, some studies also specify certain inefficiencies due to the possible presence of socialism (Scharfstein \& Stein, 2000) and minority shareholder expropriation (Bertrand, Mehta, \& Mullainathan, 2002). In addition, moral hazard problems can arise as affiliated firms are separate legal entities with their own limited liability. As a result, groups may extract resources from their affiliates and even let these firms go bankrupt without major consequences for the other group members (see e.g., Bianco \& Nicodano, 2006).

This study contributes to the literature by examining the cash policies of business group affiliates. First, by comparing affiliates with a matched sample of non-affiliated firms, this study pinpoints the impact of group membership on cash policy. Second, this research extends the cash models of affiliates by systematically including both affiliate level and group level characteristics. In this way, the analyses show how group level variables complement individual affiliate characteristics in the design of affiliates' cash policy. Third, this paper evaluates the link between the firm's cash policy and the financial health of the group and provides empirical evidence on the manner in which groups differentiate between affiliates in case of group distress. Overall, this research provides additional insights into the functioning of internal capital 
markets and sheds more light on the use of financial resources within groups.

The existing empirical evidence concerning the cash policies of business group affiliates is extremely scarce. Without making a strict distinction between non-affiliated firms and affiliates, Deloof (2001) reports that intra-group claims negatively affect cash holdings. Pinkowitz and Williamson (2001) focus on the impact of bank power on cash holdings and find that keiretsu members hold less cash than non-member firms.

This study uses a panel of large non-financial affiliates of private Belgian domestic business groups and comparable private nonaffiliated firms. This sample has several appealing properties. Firstly, as a typical Western European civil law country in a mature market economy, Belgium provides a particularly attractive setting for this study. This country has the highest presence of pyramidal structures and controlling shareholders compared to other industrialized countries (La Porta et al., 1999), and while many studies find evidence of the expropriation of minority shareholders in emerging markets (see e.g., Bertrand et al., 2002; George \& Kabir, 2008), Buysschaert, Deloof, and Jegers (2004) show that, on average, equity sales within Belgian business groups create wealth for minority shareholders. In addition, Belgian accounting law obliges large companies to provide information on intra-group transactions in the notes to the financial statements, which is essential to be able to distinguish between affiliated and non-affiliated firms. Secondly, few studies focus on private business groups, though this type of organizations is a very important economic force. For instance, Dewaelheyns and Van Hulle (2010) report that up to one third of the largest non-financial firms in the Eurozone have ties to private business groups. In addition, comparing private non-affiliated firms to affiliates of private business groups allows for developing clean hypotheses by limiting the impact of external equity financing.

Previewing the main results, the analysis shows that the cash policy of affiliates and non-affiliated firms differs after controlling for firm-specific determinants of cash. Business group members hold smaller amounts of cash on their balance sheets than comparable non-affiliated firms. In addition, business group membership enhances or lessens the relationship between certain firm characteristics and cash, though not always as optimization arguments would predict. The data also show that group health affects affiliates' cash policy. More specifically, financial distress at group level negatively affects the cash holdings of business group affiliates, even after controlling for several group level and affiliate level characteristics.

Yet, affiliates that receive intra-group guarantees, generate a large part of the total group's sales, or are active in the core industry of the group hold cash reserves comparable to affiliates belonging to financially healthy groups. This result suggests that groups in distress focus on maintaining sufficiently high cash levels in affiliates that are important for group survival. Overall, the evidence supports the notion of optimization behavior within groups, even though some room for improvement remains.

The remainder of the paper proceeds as follows. Section 2 develops hypotheses concerning the cash holdings of affiliates and discusses the control variables used in the analysis. Section 3 describes the sample and provides univariate statistics and tests. Section 4 contains the results of the multivariate empirical analyses. Finally, Section 5 concludes.

\section{Cash policy and business groups}

\subsection{Hypotheses}

Business groups consist of a set of legally distinct entities under the control of a large corporate owner. The legal independence of business group affiliates preserves their limited liability in case of the failure of a fellow affiliate and enables them to obtain external financing, which contrasts with the theoretical conglomerate literature that often assumes that divisions only receive funds from headquarters (e.g., Gertner, Scharfstein, \& Stein, 1994; Stein, 1997). Because of these characteristics business groups differ from other organizational forms such as multidivisional firms or conglomerates wherein divisions or subsidiaries are legally consolidated (see e.g., Duchin, 2010). In addition to external financing, affiliates have access to the internal capital market of the group through which the group allocates financial resources. Bianco and Nicodano (2006), Dewaelheyns and Van Hulle (2010) and Schiantarelli and Sembenelli (2000) among others suggest that group-wide optimization is an important force in this process. This study uses optimization as a benchmark to develop testable hypotheses.

The literature on internal capital markets suggests several reasons why affiliates should hold less cash than non-affiliated firms. First of all, because of lower information asymmetries between group firms, internal capital markets allow for the mitigation of information and contract enforcement problems typical of external financing. More specifically, Gertner et al. (1994) show that the owner-provided nature of internal debt leads to higher monitoring incentives resulting in lower information asymmetries and enhanced allocation of resources. Hoshi, Kashyap, and Scharfstein (1990) posit that these smaller information asymmetries also cause a decrease in costs of financial distress because of more easy renegotiable debt contracts. In this respect, Deloof (2001) demonstrates that affiliates adjust intra-group trade credit terms to fit their liquidity needs. Second, affiliation can improve the affiliates' debt bearing capacity. Group reputation facilitates access to external credit (Chang \& Hong, 2000; Manos, Murinde, \& Green, 2007; Schiantarelli \& Sembenelli, 2000). In addition, intra-group guarantees also enhance the availability of external financing as assets of one group member can serve as collateral for other affiliates, thereby averting credit rationing (Chang \& Hong, 2000; Ghatak \& Kali, 2001; Verschueren \& Deloof, 2006).

These arguments lead to the first hypothesis.

H1. Business group affiliates hold less cash than non-affiliated firms.

Several group characteristics play an important role in the internal capital market's funding capacity (e.g., Dewaelheyns \& Van Hulle, 2010; Manos et al., 2007). As measures of overall group financial health or distress encompass several of these variables - such as group leverage and group profitability - group financial distress likely has an important effect on affiliates' cash policy. However, the expected relationship between group financial distress and the cash holdings of affiliates is ambiguous.

On the one hand, companies should increase their cash levels in order to reduce costs of financial distress and overall default risk (Ferreira \& Vilela, 2004; Garcìa-Teruel \& Martìnez-Solano, 2008). This increase in cash in times of distress may more likely occur within affiliates than within non-affiliated firms, as groups have more opportunities to generate resources (e.g., by selling non-crucial assets and affiliates). On the other hand, groups in distress may not succeed in this objective and cash holdings of affiliates may even decline as group-wide financial distress puts the group under pressure to meet contractual obligations (Garcìa-Teruel \& Martìnez-Solano, 2008; Kim, Mauer, \& Sherman, 1998).

The relationship between group financial distress and cash remains an empirical question and, therefore, results in the following second hypothesis.

H2. The cash holdings of affiliates depend on group financial distress.

Group level distress need not affect the cash levels of all affiliates in the same manner. Certain types of affiliates are more vital for the group's operations and/or reputation than others. The failure of such vital affiliates may have strong negative effects on the functioning and overall survival chances of a financially distressed group. Therefore, distressed groups may treat affiliates differently depending on the affiliates' importance for group survival.

Several factors could cause a difference in treatment. First, empirical findings suggest that affiliates active in the group's core industry are more important for the group's reputation and operations in case of distress. Lamont (1997) finds that an adverse shock in the group's 
cash flows affects the investments of non-core divisions more strongly. Dewaelheyns and Van Hulle (2006) show that groups in distress are less likely to support business group members primarily active in an industry that is non-core to the group. The contribution of an affiliate's sales to total group sales may also influence group decisions: the failure of an affiliate that generates a large fraction of group sales can easily endanger the survival of the whole group. Third, the bankruptcy of affiliates that have received guarantees from other group members may have particularly important negative effects on the business group as a whole. If these affiliates fail, external creditors will claim payment from the group members acting as guarantors, which in turn further propagates problems throughout the group's structure.

In sum, the importance of affiliates for the group's operations and/ or reputation may cause a different effect of group financial distress on the cash policy of affiliates. However, as $\mathrm{H} 2$ does not provide a clear-cut answer regarding the direction of the relationship between group financial distress and cash, two scenarios are possible. If affiliates of distressed groups hold larger amounts of cash than affiliates of financially healthy groups, this effect likely holds for those firms which are most important for group survival. Alternatively, if group distress causes affiliates to hold smaller amounts of cash than affiliates of healthy groups, this relationship is more likely to dominate for less vital affiliates. Thus, one of the two following hypotheses should hold.

H3. Relative to the cash holdings of affiliates of healthy groups: (a) if cash levels in affiliates of distressed groups are higher on average, the cash reserves of affiliates that are important to group survival will increase more; (b) if cash levels in affiliates of distressed groups are lower on average, the cash reserves of affiliates that are important to group survival will decrease less.

\subsection{Firm-specific antecedents of cash}

The cash literature identifies a number of firm-specific determinants that are important in explaining cash levels. Table 1 details the definitions of these discussed control variables.

\subsubsection{Size}

Transaction cost models show the presence of economies of scale in cash management (e.g., Baumol, 1952). Also, smaller firms face higher borrowing constraints and more likely suffer from financial distress due to higher information asymmetries (Berger, Klapper, \& Udell, 2001; Fazzari \& Petersen, 1993; Kim et al., 1998). These arguments imply that smaller firms hold more cash to be able to finance their activities.

\subsubsection{Leverage}

According to the literature, the impact of leverage on cash holdings may be ambiguous. First of all, Baskin (1987) argues that the opportunity cost of holding cash rises when leverage increases. Firms with higher levels of outstanding debt may also have a higher ability to raise external funds (Ferreira \& Vilela, 2004). Therefore, more highly levered firms would hold less cash. By contrast, higher levels of leverage also increase the possibility of financial distress. To reduce bankruptcy risk, firms may increase cash levels when leverage rises implying that more highly levered firms hold more cash (Ferreira \& Vilela, 2004).

\subsubsection{Growth opportunities}

Myers (1977) and Myers and Majluf (1984) show that high growth firms face higher information asymmetries and, therefore, face more borrowing constraints. As a result, firms with more growth opportunities hold more cash to avoid losing valuable investment opportunities due to a shortage of funds (Opler, Pinkowitz, Stulz, \& Williamson, 1999).

\subsubsection{Cash flow}

Kim et al. (1998) posit that cash flows are a substitute for cash. In this view, firms with higher cash flows hold less cash. However,
Table 1

Variable definitions.

\begin{tabular}{|c|c|}
\hline Variables & Definitions \\
\hline CASH & $\begin{array}{l}\left(\text { Cash }_{t}+\text { marketable securities }_{t}\right) / \text { net assets } \\
\text { total with net assets } \\
\text { assets }\end{array}$ \\
\hline SIZE & $\operatorname{Ln}\left(\right.$ real total assets $\left._{t}\right)$ \\
\hline LEV & $\left(\right.$ ST liabilities $t+$ LT liabilities $\left.{ }_{t}\right) /$ total $_{\text {assets }}$ \\
\hline GROWTH & $\left(\right.$ Sales $_{t} /$ sales $_{t-1}+$ sales $_{t-1} /$ sales $\left._{t-2}\right) / 2$ \\
\hline $\mathrm{CF}$ & $\begin{array}{l}\text { Earnings }_{\mathrm{t}} \text { after interests and taxes }+ \text { net depreciation } \\
\mathrm{t} \text { and } \\
\left.\text { amortization }_{\mathrm{t}}\right) / \text { net assets }\end{array}$ \\
\hline CF UNCERTAINTY & $\left.\sigma \mathrm{CF}_{\mathrm{t},} \mathrm{CF}_{\mathrm{t}-1,} \mathrm{CF}_{\mathrm{t}-2}\right)$ \\
\hline LIQ & $\left(\right.$ Working capital $_{\mathrm{t}}-$ cash $_{\mathrm{t}}-$ marketable securities $\left._{\mathrm{t}}\right) /$ net assets $\mathrm{t}$ \\
\hline CAPEX & $\begin{array}{l}\left(\text { Nettangible }_{\text {assets }}-\text { nettangible assets }_{\mathrm{t}-1}+\text { depreciation }_{\mathrm{t}}\right) / \\
\text { net assets } \\
\mathrm{t}\end{array}$ \\
\hline GROUP & $\begin{array}{l}\text { Dummy variable: } 1 \text { if the firm is a business group member; } 0 \\
\text { otherwise }\end{array}$ \\
\hline GROUPSIZE & $\operatorname{Ln}\left(\right.$ total group assets $\left.{ }_{t}\right)$ \\
\hline GROUPAGE & $\operatorname{Ln}\left(\right.$ group age $\left._{t}\right)$ \\
\hline GROUPDISTRESS1 & 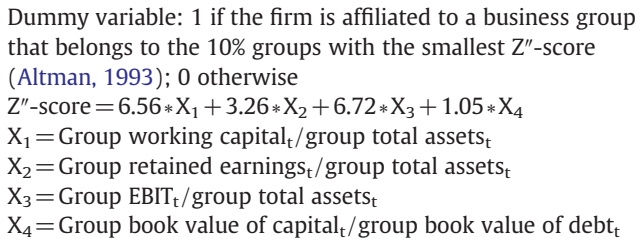 \\
\hline \multirow[t]{6}{*}{ GROUPDISTRESS2 } & $\begin{array}{l}\text { Dummy variable: } 1 \text { if the firm is affiliated to a business group } \\
\text { that belongs to the } 10 \% \\
\text { groups with the smallest MM-score (Mackie-Mason, 1990); } 0 \\
\text { otherwise }\end{array}$ \\
\hline & MM-score $=3,3 * \mathrm{X}_{1}+1,0 * \mathrm{X}_{2}+1,4 * \mathrm{X}_{3}+1,2 * \mathrm{X}_{4}$ \\
\hline & 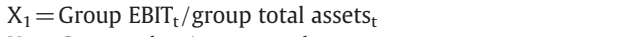 \\
\hline & $\mathrm{X}_{2}=$ Group sales $_{\mathrm{t}} /$ group total assets $_{\mathrm{t}}$ \\
\hline & $\mathrm{X}_{3}=$ Group retained earnings $_{\mathrm{t}} /$ group total $_{\text {assets }} \mathrm{t}$ \\
\hline & 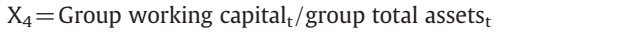 \\
\hline CORE & $\begin{array}{l}\text { Dummy variable: } 1 \text { if the affiliate is active in the same industry } \\
\text { as the core industry of the parent; } 0 \text { otherwise }\end{array}$ \\
\hline LARGE & $\begin{array}{l}\text { Dummy variable: } 1 \text { if sales / group sales } \geq \text { median sample } \\
\text { sales /group sales; } 0 \text { otherwise }\end{array}$ \\
\hline GUARANTEE & $\begin{array}{l}\text { Dummy variable: } 1 \text { if the affiliate has received intra-group } \\
\text { guarantees; } 0 \text { otherwise }\end{array}$ \\
\hline
\end{tabular}

internally generated funds may also positively affect cash holdings. Myers and Majluf (1984) show that firms prefer to finance activities with internally generated funds due to information asymmetries. Therefore, after controlling for capital expenditures, firms with high cash flow generation hold more cash as they have more opportunities to build up these financial reserves (Opler et al., 1999).

\subsubsection{Cash flow uncertainty}

The more volatile the firm's cash flows, the higher the likelihood that the cash flows are insufficient to cover the outlays. Therefore, cash flow uncertainty affects cash holdings positively (Opler et al., 1999).

\subsubsection{Liquid substitutes}

Non-cash liquid assets also influence cash holdings as firms can more easily liquidate these assets when a cash shortage arises. Hence, firms that hold more liquid assets hold less cash (Ferreira \& Vilela, 2004).

\subsubsection{Sensitivity effects}

Preceding arguments concerning firm-specific drivers of cash reserves hold for both non-affiliated firms and affiliates. However, as the latter can also access an internal capital market to obtain funding, affiliation may strengthen or weaken the relationship between these firmspecific control variables and cash holdings. As affiliates increase in size, they can combine the benefits of scale with the advantage of lower information asymmetries because of the owner-provided nature of internal debt (cf., Gertner et al., 1994), which further reduces transaction costs. Therefore, the negative relationship between size and cash is likely stronger for affiliates as compared to non-affiliated firms. The use of 
intercompany loans should reduce the opportunity cost of debt for affiliates and concerns about bankruptcy risk ought to be lower as affiliates can rely on the internal capital market.

Hence, leverage should less strongly affect the cash holdings of affiliates. As affiliates are able to finance their growth needs with internal debt, growth opportunities may less positively affect affiliates' cash holdings. Similarly, affiliates' cash flows should have a smaller impact on cash as internal capital markets reduce information asymmetries. Considering cash flow uncertainty, business group membership likely lessens the need for affiliates to hold cash in order to hedge against cash flow shortages as these firms can resort to the internal capital market. Therefore, cash flow uncertainty should have less of an impact on cash reserves. Finally, affiliates can more easily adjust the terms of intra-group trade credit to fill their liquidity needs resulting in a more negative effect of non-cash liquid substitutes on cash (Deloof, 2001).

\subsection{Group-specific variables}

Besides group financial health and the firm-specific variables, group size and age may have an impact upon the group's capacity to provide funding for affiliates through the internal capital market or ease access to external financing.

\subsubsection{Group size}

As the size of the group increases, more funds are available for intra-group transactions as well as more assets for intra-group guarantees to support external financing (Chang \& Hong, 2000). In addition, larger groups suffer less from information asymmetries with regard to external providers of credit (Manos et al., 2007). Both preceding arguments suggest a negative impact of group size on the amount of cash held by affiliated firms. Finally, economies of scale at group level could also induce affiliates to hold less cash.

\subsubsection{Group age}

Similarly to the size of the group, the group's age may proxy for the size of the internal capital market as older groups have had more opportunities to accumulate funds over time. In addition, older groups often have more solid long-term relationships with lenders and hence may have a stronger reputation in the external capital market (Diamond, 1991). As affiliated firms share in their group's reputation, affiliates can obtain external funds more easily when belonging to a group that enjoys a good reputation (Chang \& Hong, 2000). These arguments suggest that affiliates of an older group hold less cash.

Besides group size and group age, the total amount of group leverage and group profitability may also affect the funding capacity of the internal capital market (Dewaelheyns \& Van Hulle, 2010). Nevertheless, the subsequent analysis does not incorporate these variables because the group's financial health scores are linear combinations of these financial ratios, among others, and could lead to collinearity problems in the multivariate models.

\section{Sample and descriptive statistics}

\subsection{Sample selection}

The dataset contains financial and ownership information concerning private Belgian non-financial firms filing unconsolidated complete annual accounts for at least 4 consecutive fiscal years from 1998 until 2007 (Bureau Van Dijk EP's Belfirst database). The ownership information allows for the construction of two samples: an affiliate sample including members of private non-financial domestic business groups and a sample containing private non-affiliated companies. This study defines a firm as a business group affiliate if the controlling company of the group holds directly or indirectly - at least $50 \%$ of the firm's shares.

In addition, the affiliate sample only includes operating affiliates of domestic business groups that file consolidated accounts at group level. If some of these selected affiliates are the only or dominant operating affiliate of the group, this study considers the controlling corporate shareholder of the group as a shell company and excludes these firms from the analysis. Next, the non-affiliated sample contains firms of which the largest corporate shareholder does not directly or indirectly hold a stake of $20 \%$ or more in the company and the firm does not report the use of internal debt. This double criterion minimizes the risk of classification errors (Dewaelheyns \& Van Hulle, 2010).

Following common practice, this study omits firm-years with zero cash holdings, zero sales and firm-years with extremely high leverage levels (above $100 \%$ of total assets). Both samples also exclude firms in certain industries because of the specific nature of their activities such as utilities, financial firms and several categories of service companies (e.g., real estate). This sample selection process results in an affiliate sample of 1129 affiliated firms (5541 firm-years) part of 442 business groups and a non-affiliate sample of 2961 non-affiliated firms (14,799 firm-years). Finally, the testing sample matches non-affiliated firms with the affiliated companies in terms of industry (two digits NACE-BEL 2003) and size (average deflated total assets) to improve comparability across samples (Dewaelheyns \& Van Hulle, 2010), which results in a sample of 1129 non-affiliated firms (5491 firm-years). As a robustness test, an alternative testing sample matches every affiliate with a non-affiliated company on the basis of propensity score matching to control for possible selection and omitted variable issues with respect to the group membership decision. One procedure matches both samples on industry and average firm size and a second procedure includes the average firm-level and industry-level instruments following Campa and Kedia (2002). The results remain qualitatively the same. A replication of the analyses involving all firms before the matching procedure yields similar results as well.

\subsection{Univariate statistics}

Table 2 presents descriptive statistics and univariate tests for both the non-affiliated (NA) and affiliate (A) sample. The left-hand side of Table 2 reports the medians along with the minimum and maximum between brackets; the right-hand side shows the means accompanied by the standard deviation between brackets. Table 2 also reports Z-statistics from the Wilcoxon Mann-Whitney equality of medians test and t-statistics from the t-tests for the equality of means. Finally, this study winsorizes all continuous variables at the $1 \%$ and $99 \%$ levels to reduce the potential impact of outliers, though non-winsorized variables do not change the main results.

The univariate tests show that most company characteristics differ between both samples. A first important observation is that non-affiliated firms hold larger amounts of cash (CASH) on their balance sheets as compared to affiliates at both the median and mean levels. This result is consistent with $\mathrm{H} 1$.

Although size was one of the two matching criteria, affiliates remain significantly larger (SIZE) than their independent counterparts. In addition, affiliates have significantly smaller leverage ratios (LEV). However, the differences in size and leverage between both samples are not likely to be important in economic terms. The median growth rate (GROWTH) is slightly smaller for the affiliate sample; however, the mean growth rate is slightly larger. Affiliates show smaller (CF) and more volatile (CF UNCERTAINTY) cash flow ratios. Non-cash liquid substitutes (LIQ) do not differ between both samples at the mean level. Although the median non-cash liquid substitutes are significantly larger for the non-affiliated sample, the difference is small in economic terms. Finally, capital expenditures (CAPEX) are significantly smaller for affiliated firms.

Turning to the univariate statistics concerning the group level variables, median group size is much larger than median affiliate size indicating that the sample selection process effectively omits groups that function as shell companies. Nonetheless, the median affiliate is 
Table 2

Descriptive statistics and univariate tests.

\begin{tabular}{|c|c|c|c|c|c|c|}
\hline \multirow[t]{2}{*}{ Variable } & \multicolumn{2}{|c|}{ Median [Min;Max] } & \multirow{2}{*}{$\begin{array}{l}\text { Wilcoxon Mann-Whitney } \\
\text { equality of medians test }\end{array}$} & \multicolumn{2}{|c|}{ Mean [StDev] } & \multirow{2}{*}{$\begin{array}{l}\text { Equality of means } \\
\text { t-test }\end{array}$} \\
\hline & NA & A & & NA & A & \\
\hline \multicolumn{7}{|c|}{ Firm-specific characteristics } \\
\hline CASH & $\begin{array}{l}0.089 \\
{[0 ; 3.239]}\end{array}$ & $\begin{array}{l}0.050 \\
{[0 ; 2.260]}\end{array}$ & $(17.182)^{a}$ & $\begin{array}{l}0.254 \\
{[0.48]}\end{array}$ & $\begin{array}{l}0.174 \\
{[0.35]}\end{array}$ & $(9.982)^{\mathrm{a}}$ \\
\hline SIZE & $\begin{array}{l}8.528 \\
{[4.958 ; 10.757]}\end{array}$ & $\begin{array}{l}8.752 \\
{[4.904 ; 12.390]}\end{array}$ & $(-11.383)^{\mathrm{a}}$ & $\begin{array}{l}8.355 \\
{[1.18]}\end{array}$ & $\begin{array}{l}8.685 \\
{[1.60]}\end{array}$ & $(-12.323)^{a}$ \\
\hline LEV & $\begin{array}{l}0.654 \\
{[0.061 ; 0.987]}\end{array}$ & $\begin{array}{l}0.642 \\
{[0.027 ; 0.972]}\end{array}$ & $(3.900)^{\mathrm{a}}$ & $\begin{array}{l}0.614 \\
{[0.24]}\end{array}$ & $\begin{array}{l}0.597 \\
{[0.24]}\end{array}$ & $(3.716)^{\mathrm{a}}$ \\
\hline GROWTH & $\begin{array}{l}1.036 \\
{[0.569 ; 2.847]}\end{array}$ & $\begin{array}{l}1.025 \\
{[0.520 ; 3.441]}\end{array}$ & $(4.191)^{\mathrm{a}}$ & $\begin{array}{l}1.079 \\
{[0.27]}\end{array}$ & $\begin{array}{l}1.091 \\
{[0.37]}\end{array}$ & $(-1.808)^{\mathrm{c}}$ \\
\hline $\mathrm{CF}$ & $\begin{array}{l}0.105 \\
{[-0.203 ; 0.728]}\end{array}$ & $\begin{array}{l}0.087 \\
{[-0.255 ; 0.603]}\end{array}$ & $(9.216)^{\mathrm{a}}$ & $\begin{array}{l}0.135 \\
{[0.14]}\end{array}$ & $\begin{array}{l}0.114 \\
{[0.13]}\end{array}$ & $(8.167)^{\mathrm{a}}$ \\
\hline CF UNCERTAINTY & $\begin{array}{l}0.025 \\
{[0.001 ; 0.446]}\end{array}$ & $\begin{array}{l}0.029 \\
{[0.002 ; 0.511]}\end{array}$ & $(-7.571)^{\mathrm{a}}$ & $\begin{array}{l}0.045 \\
{[0.07]}\end{array}$ & $\begin{array}{l}0.053 \\
{[0.07]}\end{array}$ & $(-5.484)^{\mathrm{a}}$ \\
\hline LIQ & $\begin{array}{l}0.059 \\
{[-1.293 ; 0.687]}\end{array}$ & $\begin{array}{l}0.052 \\
{[-0.944 ; 0.827]}\end{array}$ & $(1.830)^{\mathrm{b}}$ & $\begin{array}{l}0.055 \\
{[0.31]}\end{array}$ & $\begin{array}{l}0.056 \\
{[0.30]}\end{array}$ & $(-0.0834)$ \\
\hline CAPEX & $\begin{array}{l}0.041 \\
{[-0.079 ; 0.513]}\end{array}$ & $\begin{array}{l}0.021 \\
{[-0.134 ; 0.497]}\end{array}$ & $(16.834)^{a}$ & $\begin{array}{l}0.078 \\
{[0.11]}\end{array}$ & $\begin{array}{l}0.053 \\
{[0.09]}\end{array}$ & $(13.117)^{a}$ \\
\hline \multicolumn{7}{|c|}{ Group characteristics } \\
\hline GROUPSIZE & - & $\begin{array}{l}11.002 \\
{[9.148 ; 14.619]}\end{array}$ & - & - & $\begin{array}{l}11.216 \\
{[1.18]}\end{array}$ & - \\
\hline GROUPAGE & - & $\begin{array}{l}2.773 \\
{[0 ; 4.898]}\end{array}$ & - & - & $\begin{array}{l}2.865 \\
{[1.05]}\end{array}$ & - \\
\hline
\end{tabular}

Notes: variables as defined in Table 1.

a Denotes significance at the $1 \%$ level.

b Denotes significance at the $5 \%$ level.

c Denotes significance at the $10 \%$ level.

sufficiently large to be important for the group's structure since the total assets of the median affiliate amounts to $10 \%$ of the total consolidated assets of the median group. In addition, the affiliate sample consists of affiliates of mature groups with well-established internal capital markets as the median group age is 16 years.

\section{Regression results}

Table 3 first shows the results for the base line models (1), (2) and (3). Model (1) encompasses the full sample of affiliated and matched non-affiliated firms, while models (2) and (3) show the findings for the separate subsamples. In addition, models (4) and (5) extend the base line model for affiliated firms by incorporating group level variables. All models include time and industry fixed effects. The standard errors are robust for firm-level clustering for non-affiliated firms and group-level clustering for affiliates. The correction for the latter type of companies should occur at the most aggregated level (Cameron, Gelbach, \& Miller, 2006). Finally, all models employ the natural logarithm of cash to net assets ratio as the independent variable (e.g., Opler et al., 1999). The results do not change if the regression analyses employ the ratio of cash to total assets instead.

First of all, model (1) includes a dummy variable (GROUP), which takes a unit value if a firm is a business group member and a zero when the firm is defined to be a non-affiliated firm. The estimated coefficient is negative and significant. In line with $\mathrm{H} 1$, this result shows that affiliated firms hold less cash than comparable non-affiliated firms after controlling for other cash determinants. Next, model (1) shows that all company-level characteristics significantly explain the firms' cash levels in the full sample, except for growth opportunities. In line with the earlier discussed conjectures, larger firms (SIZE) hold significantly smaller amounts of cash. Also, more highly leveraged (LEVERAGE) firms hold less cash. This result supports the notion that more highly levered firms incur higher opportunity costs of holding cash (Baskin, 1987) and/or have a higher ability to obtain external credit (Ferreira \& Vilela, 2004). The results also show that internally generated funds (CF) are important drivers of cash. In line with the arguments of Myers and Majluf (1984), firms with a higher cash flow generation hold more cash after controlling for investment expenditures. Firms that have a more volatile cash flow (CF UNCERTAINTY) hold more cash to hedge against cash flow risk. As a robustness check, the analyses also incorporate cash flow volatilities that cover periods of 4 to 6 years (not reported). These modifications do not change the results. Non-cash liquid substitutes (LIQ) and capital expenditures (CAPEX) have a negative influence on cash. Overall, preceding results are in line with expectations and with the results found in the literature.

Finally, preceding results hold even in the face of a possible simultaneity bias. Although several firm-specific characteristics may simultaneously drive both the firm's cash and the debt policy (Acharya, Almeida, \& Campello, 2007), the approach followed in this study yields correct results as the system of simultaneous equations involving cash and debt as dependent variables proves to be recursive, making simultaneous-system estimation redundant (Hooks, 2003). Further robustness tests (not reported) replace the leverage variable with the residuals of the auxiliary regressions of leverage on size, cash flow, growth opportunities and capital expenditures to control for collinearity problems (Dewaelheyns \& Van Hulle, 2010; Johnson, 1997). The main results remain unaltered. Reduced form regressions that exclude leverage and liquid substitutes do not change the results either. As Iskandar-Datta and Yonghong (2012) show that time patterns significantly drive the cash holdings of firms, the analysis also incorporates these effects (not reported). Time patterns do neither seem to matter for the cash holdings of Belgian private firms, nor does their inclusion influence the results. Finally, re-estimating the models using the Heckman procedure with a selection model for group membership based on Campa and Kedia (2002) does not alter the main results.

The general relationships between cash and firm characteristics are the same for both non-affiliated and affiliated firms. In order to evaluate differences in the magnitudes of the coefficients between subsamples concerning these control variables, an extended version of model (1) (not reported) allows for all coefficients to differ across non- 
Table 3

Antecedents of Cash holdings.

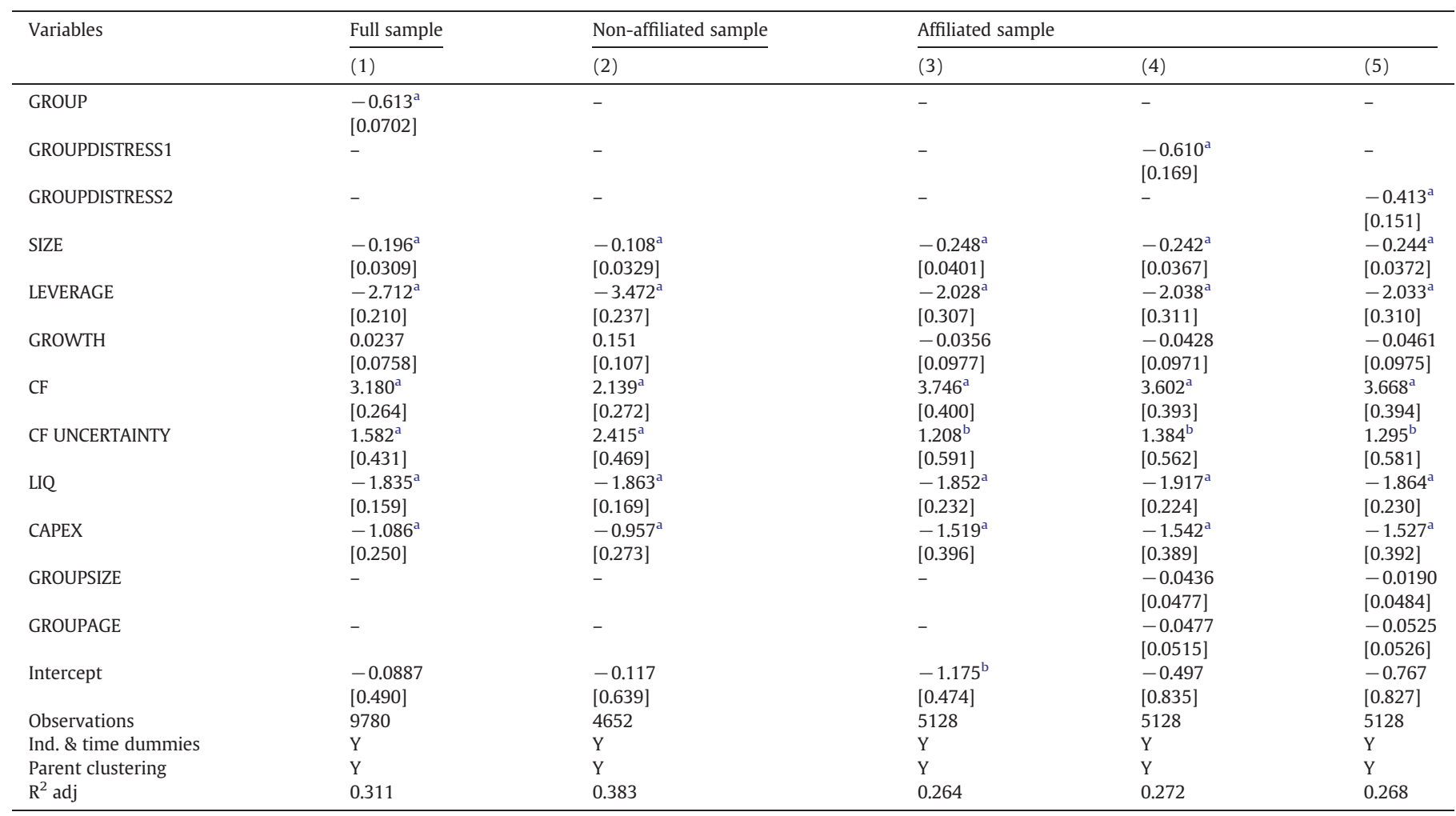

Notes: the dependent variable is the natural logarithm of the cash to net assets ratio. Independent variables as defined in Table 1. Standard errors between brackets.

a Denotes significance at the $1 \%$ level.

b Denotes significance at the $5 \%$ level.

c Denotes significance at the $10 \%$ level.

affiliated and affiliated companies by introducing interaction terms for each firm-specific variable and the group dummy. In this model, the group dummy remains negative and significant $(t-s t a t=-9.04)$.

The results also indicate that affiliation affects the impact of certain control variables on cash. Firm size has a significantly stronger negative effect on cash for affiliated firms as compared to non-affiliated firms in line with expectations ( $t$-stat $=-3.4$ ). Leverage has a less negative effect on cash suggesting that business group affiliates are less sensitive to the opportunity cost of holding cash ( $\mathrm{t}$-stat $=4.2$ ). The impact of growth opportunities on cash does not differ across samples ( $t$-stat $=-0.98$ ). In addition, affiliation increases the impact of cash flows on cash suggesting that affiliates hold some financial slack on their balance sheets ( $\mathrm{t}$-stat $=$ 3.34). Confirming expectations, affiliates hold smaller amounts of cash to hedge against cash flow risk as these firms can resort to an internal capital market when needed ( $t$-stat $=-1.79$ ). Next, the results show no significant difference between affiliates and non-affiliated firms concerning the impact of non-cash liquid assets $(\mathrm{t}$-stat $=0.56)$ and capital expenditures on cash ( $t$-stat $=-1.61)$. Overall, these results indicate that groups make use of the opportunities embedded in their organizational structure to reduce cash in affiliates, though some slack seems to remain.

Models (4) and (5) examine the impact of group financial distress on affiliates' cash holdings by introducing group financial distress dummies. These models also include GROUPAGE and GROUPSIZE as group-specific control variables. In order to distinguish a healthy group from a group in distress, this study defines a group as financially distressed if the group belongs to the $10 \%$ of sample groups with the lowest financial health score (Berger et al., 2001). The employed measure of financial health is an adapted and re-estimated version of the Altman (1968) Z-score for private firms, namely the Z"-score (Altman, 1993) (GROUPDISTRESS1). As a robustness test, the analysis also incorporates a group financial distress dummy on the basis of Mackie-Mason's (1990) measure of bankruptcy risk (GROUPDISTRESS2). The Mackie-Mason (MM)-score does not include an equity measure and, hence, is an attractive measure of financial health for a sample of private firms.

Supportive of $\mathrm{H} 2$, the group distress dummy is highly significant in both models. The negative sign supports the notion that affiliates of financially distressed groups hold smaller amounts of cash as compared to those of healthy ones as financial distress puts pressure on firms to meet commitments. The results prove to be robust for higher (i.e., 12.5\%) or lower (i.e., 7.5\%) distress cut-offs. To further check robustness, models (5) and (6) also employ the natural logarithm of cash as a dependent variable as the asset base may change for firms in distress. The results do not change. Finally, the remaining group level variables have the expected signs, but are not significant.

Although preceding findings indicate that unhealthy groups reduce overall cash levels of affiliates, the question remains whether or not business groups differentiate between different types of affiliates in case of distress (H3). The first three models of Table 4 report the findings using GROUPDISTRESS1, while the last three models include GROUPDISTRESS2.

Models ( 1 ) and ( $\left.1^{\prime}\right)$ consider the impact of the affiliates' main activity. Both models show that the cash reserves of affiliates of a distressed group that are active within the core industry of the parent (CORE) remain at levels comparable to those in affiliates of healthy groups. By contrast, the cash holdings of affiliates that are active in non-core industries (1-CORE) undergo a negative and significant effect of group financial distress as compared to affiliates of healthy groups. These results are in line with H3(b) and with the findings of Dewaelheyns and Van Hulle (2006) and Lamont (1997).

The importance of an affiliate for total sales generation within a distressed group may also affect the affiliates' cash holdings (models 2 and $2^{\prime}$ ). Affiliates that generate a large proportion of total group 
Table 4

Antecedents of cash holdings: extended analysis.

\begin{tabular}{|c|c|c|c|c|c|c|}
\hline \multirow[t]{2}{*}{ Variables } & \multicolumn{3}{|c|}{ GROUPDISTRESS1 } & \multicolumn{3}{|c|}{ GROUPDISTRESS2 } \\
\hline & $(1)$ & $(2)$ & (3) & $\left(1^{\prime}\right)$ & $\left(2^{\prime}\right)$ & $\left(3^{\prime}\right)$ \\
\hline GROUPDISTRESS $*$ CORE & $\begin{array}{l}-0.597 \\
{[0.41]}\end{array}$ & - & & $\begin{array}{l}-0.284 \\
{[0.28]}\end{array}$ & - & \\
\hline GROUPDISTRESS $*(1-$ CORE) & $\begin{array}{l}-0.614^{\mathrm{a}} \\
{[0.15]}\end{array}$ & - & & $\begin{array}{l}-0.458^{a} \\
{[0.16]}\end{array}$ & - & \\
\hline GROUPDISTRESS $*$ LARGE & - & $\begin{array}{l}-0.0666 \\
{[0.15]}\end{array}$ & - & - & $\begin{array}{l}-0.0825 \\
{[0.15]}\end{array}$ & - \\
\hline GROUPDISTRESS *(1-LARGE) & - & $\begin{array}{l}-1.035^{\mathrm{a}} \\
{[0.25]}\end{array}$ & - & - & $\begin{array}{l}-0.836^{a} \\
{[0.25]}\end{array}$ & - \\
\hline GROUPDISTRESS $*$ GUARANTEE & - & - & $\begin{array}{l}-0.427 \\
{[0.32]}\end{array}$ & - & - & $\begin{array}{l}-0.401 \\
{[0.29]}\end{array}$ \\
\hline GROUPDISTRESS $*$ (1-GUARANTEE) & - & - & $\begin{array}{l}-0.687^{a} \\
{[0.16]}\end{array}$ & - & - & $\begin{array}{l}-0.416^{\mathrm{b}} \\
{[0.16]}\end{array}$ \\
\hline SIZE & $\begin{array}{l}-0.242^{\mathrm{a}} \\
{[0.04]}\end{array}$ & $\begin{array}{l}-0.238^{\mathrm{a}} \\
{[0.04]}\end{array}$ & $\begin{array}{l}-0.243^{\mathrm{a}} \\
{[0.04]}\end{array}$ & $\begin{array}{l}-0.245^{\mathrm{a}} \\
{[0.04]}\end{array}$ & $\begin{array}{l}-0.238^{\mathrm{a}} \\
{[0.04]}\end{array}$ & $\begin{array}{l}-0.244^{\mathrm{a}} \\
{[0.03]}\end{array}$ \\
\hline LEVERAGE & $\begin{array}{l}-2.039^{a} \\
{[0.31]}\end{array}$ & $\begin{array}{l}-2.101^{\mathrm{a}} \\
{[0.31]}\end{array}$ & $\begin{array}{l}-2.048^{a} \\
{[0.31]}\end{array}$ & $\begin{array}{l}-2.040^{\mathrm{a}} \\
{[0.31]}\end{array}$ & $\begin{array}{l}-2.082^{\mathrm{a}} \\
{[0.30]}\end{array}$ & $\begin{array}{l}-2.034^{\mathrm{a}} \\
{[0.31]}\end{array}$ \\
\hline GROWTH & $\begin{array}{l}-0.0426 \\
{[0.10]}\end{array}$ & $\begin{array}{l}-0.0395 \\
{[0.10]}\end{array}$ & $\begin{array}{l}-0.0424 \\
{[0.10]}\end{array}$ & $\begin{array}{l}-0.0447 \\
{[0.10]}\end{array}$ & $\begin{array}{l}-0.0404 \\
{[0.10]}\end{array}$ & $\begin{array}{l}-0.0461 \\
{[0.10]}\end{array}$ \\
\hline $\mathrm{CF}$ & $\begin{array}{l}3.601^{\mathrm{a}} \\
{[0.39]}\end{array}$ & $\begin{array}{l}3.546^{\mathrm{a}} \\
{[0.38]}\end{array}$ & $\begin{array}{l}3.600^{\mathrm{a}} \\
{[0.39]}\end{array}$ & $\begin{array}{l}3.657^{\mathrm{a}} \\
{[0.39]}\end{array}$ & $\begin{array}{l}3.603^{\mathrm{a}} \\
{[0.39]}\end{array}$ & $\begin{array}{l}3.668^{\mathrm{a}} \\
{[0.39]}\end{array}$ \\
\hline CF UNCERTAINTY & $\begin{array}{l}1.384^{\mathrm{b}} \\
{[0.56]}\end{array}$ & $\begin{array}{l}1.405^{\mathrm{b}} \\
{[0.55]}\end{array}$ & $\begin{array}{l}1.388^{\mathrm{b}} \\
{[0.56]}\end{array}$ & $\begin{array}{l}1.301^{\mathrm{b}} \\
{[0.58]}\end{array}$ & $\begin{array}{l}1.319^{\mathrm{b}} \\
{[0.58]}\end{array}$ & $\begin{array}{l}1.294^{\mathrm{b}} \\
{[0.58]}\end{array}$ \\
\hline LIQ & $\begin{array}{l}-1.917^{\mathrm{a}} \\
{[0.23]}\end{array}$ & $\begin{array}{l}-1.950^{\mathrm{a}} \\
{[0.22]}\end{array}$ & $\begin{array}{l}-1.915^{\mathrm{a}} \\
{[0.22]}\end{array}$ & $\begin{array}{l}-1.865^{\mathrm{a}} \\
{[0.23]}\end{array}$ & $\begin{array}{l}-1.895^{\mathrm{a}} \\
{[0.23]}\end{array}$ & $\begin{array}{l}-1.863^{\mathrm{a}} \\
{[0.23]}\end{array}$ \\
\hline CAPEX & $\begin{array}{l}-1.541^{\mathrm{a}} \\
{[0.39]}\end{array}$ & $\begin{array}{l}-1.554^{\mathrm{a}} \\
{[0.39]}\end{array}$ & $\begin{array}{l}-1.543^{\mathrm{a}} \\
{[0.39]}\end{array}$ & $\begin{array}{l}-1.519^{\mathrm{a}} \\
{[0.39]}\end{array}$ & $\begin{array}{l}-1.542^{\mathrm{a}} \\
{[0.39]}\end{array}$ & $\begin{array}{l}-1.527^{\mathrm{a}} \\
{[0.39]}\end{array}$ \\
\hline GROUPSIZE & $\begin{array}{l}-0.0436 \\
{[0.05]}\end{array}$ & $\begin{array}{l}-0.0517 \\
{[0.05]}\end{array}$ & $\begin{array}{l}-0.0417 \\
{[0.05]}\end{array}$ & $\begin{array}{l}-0.0182 \\
{[0.05]}\end{array}$ & $\begin{array}{l}-0.0283 \\
{[0.05]}\end{array}$ & $\begin{array}{l}-0.0188 \\
{[0.05]}\end{array}$ \\
\hline GROUPAGE & $\begin{array}{l}-0.0479 \\
{[0.05]}\end{array}$ & $\begin{array}{l}-0.0463 \\
{[0.05]}\end{array}$ & $\begin{array}{l}-0.0506 \\
{[0.05]}\end{array}$ & $\begin{array}{l}-0.0546 \\
{[0.05]}\end{array}$ & $\begin{array}{l}-0.0513 \\
{[0.05]}\end{array}$ & $\begin{array}{l}-0.0526 \\
{[0.05]}\end{array}$ \\
\hline INTERCEPT & $\begin{array}{l}-0.295 \\
{[1.02]}\end{array}$ & $\begin{array}{l}-0.160 \\
{[1.00]}\end{array}$ & $\begin{array}{l}-0.303 \\
{[1.01]}\end{array}$ & $\begin{array}{l}-0.669 \\
{[1.01]}\end{array}$ & $\begin{array}{l}-0.531 \\
{[1.09]}\end{array}$ & $\begin{array}{l}-0.680 \\
{[1.01]}\end{array}$ \\
\hline Observations & 5128 & 5128 & 5128 & 5128 & 5128 & 5128 \\
\hline Ind. \& time dummies & $\mathrm{Y}$ & $\mathrm{Y}$ & $\mathrm{Y}$ & $\mathrm{Y}$ & $\mathrm{Y}$ & $\mathrm{Y}$ \\
\hline Parent clustering & $\mathrm{Y}$ & $\mathrm{Y}$ & $\mathrm{Y}$ & $\mathrm{Y}$ & $\mathrm{Y}$ & $\mathrm{Y}$ \\
\hline $\mathrm{R}^{2}$ adj. & 0.272 & 0.278 & 0.272 & 0.268 & 0.271 & 0.268 \\
\hline
\end{tabular}

Notes: The dependent variable is the natural logarithm of the cash to net assets ratio. Independent variables as defined in Table 1. Standard errors between brackets.

a Denotes significance at the $1 \%$ level.

b Denotes significance at the $5 \%$ level.

c Denotes significance at the $10 \%$ level.

sales (LARGE) also show no significant effect of group financial distress on their average cash levels. On the other hand, affiliates that are less important for total sales generation (1-LARGE) suffer a significant reduction in their cash holdings as compared to affiliates of financially healthy groups. This finding also supports $\mathrm{H} 3$ (b) and suggests that affiliates that contribute a large amount to total group sales are more important for the groups' operations and accordingly receive a more preferential treatment.

Finally, models (3) and (3') show the effect of financial distress on affiliates' cash holdings depending on whether the affiliate has received guarantees from the group (GUARANTEE) or not (1-GUARANTEE). The results show that affiliates that have not received intra-group guarantees and are member of a distressed group hold significantly smaller amounts of cash as compared to affiliates belonging to healthy groups. However, the average cash levels of affiliates of distressed groups which do receive such guarantees are not significantly different from the cash levels of affiliates of financially healthy groups. This result is consistent with $\mathrm{H} 3$ (b) and suggests that intra-group guarantees help to decrease moral hazard issues within groups.

\section{Conclusion}

This paper is the first to empirically examine the impact of group membership on affiliates' cash policy using a sample of non-affiliated firms as a benchmark. To offer a more comprehensive understanding of affiliates' cash policy, the analysis includes both firm and group level characteristics and examines in detail the impact of group financial distress.

The results show that business group affiliates hold smaller amounts of cash on their balance sheets as compared to a matched sample of non-affiliated firms. Overall, groups use their organizational structure to reduce cash reserves in affiliates. Nevertheless, the results also indicate that affiliated firms may maintain some slack cash. In addition, group distress has a negative impact on affiliates' cash holdings. However, distressed groups prove to give affiliates that are important for the group's operations and/or reputation a more favorable treatment. In particular, distressed groups maintain cash reserves comparable to the cash reserves of affiliates of financially healthy groups in affiliates that receive intra-group guarantees, in affiliates that are active in the core industry of the group or generate a large part of total group sales. This selectivity highlights the potential for moral hazard problems inherent in the limited liability of individual affiliates. The preceding findings also show that intra-group guarantees help in reducing these problems.

While this study focuses on the average cash levels of affiliated firms, the comparison of the cash adjustment process between affiliates and non-affiliated firms may be an interesting topic for further research as well. One of the advantages of affiliation is the possibility to resort to an internal capital market when an adverse shock affects the affiliates' optimal cash holdings. Furthermore, a growing body of papers shows that non-affiliated firms' cash reserves can function as a buffer against predatory behavior of competitors. Whether or not the internal capital market can protect affiliates against such behavior 
could be another topic for future research. Finally, as the alleviation of financing constraints is one of the key rationales for groups to exist, the comparison of the cash policies of listed with non-listed affiliates may yield new insights as well.

\section{References}

Acharya, V. V., Almeida, H., \& Campello, M. (2007). Is cash negative debt? A hedging perspective on corporate financial policies. Journal of Financial Intermediation, 16, $515-554$.

Altman, E. (1968). Financial ratios, discriminant analysis, and the prediction of the corporate bankruptcy. Journal of Finance, 23, 589-609.

Altman, E. (1993). Corporate financial distress and bankruptcy: A complete guide to predicting and avoiding distress and profiting from bankruptcy. New York: John Wiley and Sons.

Baskin, J. (1987). Corporate liquidity in games of monopoly power. The Review of Economics and Statistics, 64, 312-319.

Baumol, W. J. (1952). The transaction demand for cash: An inventory theoretic approach. Quarterly Journal of Economics, 69, 312-319.

Berger, A., Klapper, F., \& Udell, G. (2001). The ability of banks to lend to informationally opaque small businesses. Journal of Banking E' Finance, 25, 2127-2167.

Bertrand, M., Mehta, P., \& Mullainathan, S. (2002). Ferreting out tunneling: An application to Indian business groups. Quarterly Journal of Economics, 117, 121-148.

Bianco, M., \& Nicodano, G. (2006). Pyramidal groups and debt. European Economic Review, 50, 937-961.

Buysschaert, A., Deloof, M., \& Jegers, M. (2004). Equity sales in Belgium corporate groups: Expropriation of minority shareholders? A clinical study. Journal of Corporate Finance, 10, 81-103.

Cameron, A. C., Gelbach, J. B., \& Miller, D. L. (2006). Robust inference with multi-way clustering. NBER Technical Working Paper, 327.

Campa, J. M., \& Kedia, S. (2002). Explaining the diversification discount. Journal of Finance, $57,1731-1762$

Chang, S. J., \& Hong, J. (2000). Economic performance of group-affiliated companies in Korea: Intragroup resource sharing and internal business transactions. Academy of Management Journal, 43, 429-448.

Chen, Y., \& Chuang, W. (2009). Alignment or entrenchment? Corporate governance and cash holdings in growing firms. Journal of Business Research, 62, 1200-1206.

Deloof, M. (2001). Belgian intragroup relations and the determinants of corporate liquid reserves. European Financial Management, 7, 375-392.

Dewaelheyns, N., \& Van Hulle, C. (2006). Corporate failure prediction modeling: distorted by business groups' internal capital markets? Journal of Business Finance E Accounting, 33, 909-931.

Dewaelheyns, N., \& Van Hulle, C. (2010). Internal capital markets and capital structure: Bank versus internal debt. European Financial Management, 16, 345-373.

Diamond, D. W. (1991). Monitoring and reputation: The choice between bank loans and directly placed debt. Journal of Political Economy, 99, 689-721.

Duchin, R. (2010). Cash holdings and corporate diversification. Journal of Finance, 65 , 955-992.

Fazzari, S. M., \& Petersen, B. (1993). Working capital and fixed investment: New evidence on financing constraints. The Rand Journal of Economics, 24, 328-342.
Ferreira, M. A., \& Vilela, A. (2004). Why do firms hold cash? Evidence from EMU countries. European Financial Management, 10, 295-319.

Garcì-Teruel, P. J., \& Martinez-Solano, P. (2008). On the determinants of SME cash holdings: Evidence from Spain. Journal of Business and Accountancy, 35(1-2), 127-149.

George, R., \& Kabir, R. (2008). Business groups and profit redistribution: A boon or bane for firms? Journal of Business Research, 61, 1004-1014.

Gertner, R., Scharfstein, D. S., \& Stein, J. C. (1994). Internal versus external capital markets. Quarterly Journal of Economics, 109, 1211-1230.

Ghatak, M., \& Kali, R. (2001). Financially interlinked business groups. Journal of Economics and Management Strategy, 10, 591-619.

Hooks, L. M. (2003). The impact of firm size on bank debt use. Review of Financial Economics, 12, 173-189.

Hoshi, T., Kashyap, A., \& Scharfstein, D. (1990). The role of banks in reducing the costs of financial distress in Japan. Journal of Financial Economics, 27, 67-88.

Iskandar-Datta, M. E., \& Yonghong, J. (2012). Cross-country analysis of secular cash trends. Journal of Banking \& Finance, 36, 898-912.

Johnson, S. A. (1997). An empirical analysis of the determinants of corporate debt ownership structure. The Journal of Financial and Quantitative Analysis, 32, 47-69.

Kim, C. S., Mauer, D., \& Sherman, A. E. (1998). The determinants of corporate liquidity: Theory and evidence. Journal of Financial and Quantitative Analysis, 33, 335-359.

La Porta, R., Lopez de Silanes, F., Shleifer, A., \& Vishny, R. (1999). Corporate ownership around the world. Journal of Finance, 54, 471-528.

Lamont, O. (1997). Cash flow and investment: Evidence from internal capital markets. Journal of Finance, 52, 83-109.

Mackie-Mason, J. K. (1990). Do taxes affect corporate financing decisions? Journal of Finance, 45, 1471-1493.

Manos, R., Murinde, V., \& Green, C. J. (2007). Leverage and business groups: Evidence from Indian firms. Journal of Economics and Business, 59, 443-465.

Myers, S. C. (1977). Determinants of corporate borrowings. Journal Financial Economics, 5, 147-175.

Myers, S. C., \& Majluf, N. S. (1984). Corporate financing and investment decisions when firms have information that investors do not have. Journal of Financial Economics, 20, 293-315.

Opler, T., Pinkowitz, L., Stulz, R., \& Williamson, R. (1999). The determinants and implications of corporate cash holdings. Journal of Financial Economics, 52, 3-46.

Pinkowitz, L., \& Williamson, R. (2001). Bank power and cash holdings: Evidence from Japan. Review of Financial Studies, 14, 1059-1082.

Scharfstein, D. S., \& Stein, J. C. (2000). The dark side of internal capital markets: Divisional rent-seeking and inefficient investment. Journal of Finance, 55, 2537-2564.

Schiantarelli, F., \& Sembenelli, A. (2000). Form of ownership and financial constraints Panel data evidence from leverage and investment equations. Empirica, 27, 175-192.

Stein, J. C. (1997). Internal capital markets and the competition for corporate resources Journal of Finance, 52, 83-109.

Verschueren, I., \& Deloof, M. (2006). How does intragroup financing affect leverage? Belgian Evidence. Finance Journal of Accounting, Auditing and Finance, 21, 83-108.

Yiu, D., Lu, Y., Bruton, G. D., \& Hoskisson, R. E. (2007). Business groups: An integrated model to focus future research. Journal of Management Studies, 44, 1551-1579. 